\title{
Cloning, purification, and characterization of an organic solvent-tolerant chitinase, MtCh509, from Microbulbifer thermotolerans DAU221
}

\author{
Hyo-Jung Lee ${ }^{\dagger}$, Yong-Suk Lee $^{\dagger}$ and Yong-Lark Choi
}

\begin{abstract}
Background: The ability to use organic solvents in enzyme reactions offers a number of industrially useful advantages. However, most enzymes are almost completely inactive in the presence of organic solvents. Thus, organic solvent-tolerant enzymes have potential applications in industrial processes.

Results: A chitinase gene from Microbulbifer thermotolerans DAU221 (mtch509) was cloned and expressed in Escherichia coli BL21 (DE3). The molecular weight of the expressed MtCh509 protein was approximately $60 \mathrm{kDa}$, and it was purified by His-tag affinity chromatography. Enzymatic assays showed that the optimum temperature for MtCh509 chitinase activity was $55^{\circ} \mathrm{C}$, and the enzyme was stable for $2 \mathrm{~h}$ at up to $50^{\circ} \mathrm{C}$. The optimum pH for MtCh509 activity was in the sub-acidic range, at pH 4.6 and 5.0. The activity of MtCh509 was maintained in presence of $1 \mathrm{M}$ salt, gradually decreasing at higher concentrations, with residual activity (20\%) detected after incubation in $5 \mathrm{M}$ salt. Some organic solvents (benzene, DMSO, hexane, isoamyl alcohol, isopropyl alcohol, and toluene; 10-20\%, v/v) increased the reactivity of MtCh509 relative to the aqueous system. When using $\mathrm{NAG}_{3}$, as a substrate, MtCh509 produced $\mathrm{NAG}_{2}$ as the major product, as well as $\mathrm{NAG}_{4}$, demonstrating that MtCh509 has transglycosylation activity. The $K_{\mathrm{m}}$ and $V_{\max }$ values for MtCh509 using colloidal chitin as a substrate were $9.275 \mathrm{mg} / \mathrm{mL}$ and $20.4 \mathrm{U} / \mathrm{mg}$, respectively. Thus, MtCh509 could be used in extreme industrial conditions.
\end{abstract}

Conclusion: The results of the hydrolysate analysis and the observed increase in enzyme activity in the presence of organic solvents show that MtCh509 has industrially attractive advantages. This is the first report on an organic solvent-tolerant and transglycosylating chitinase from Microbulbifer species.

Keywords: Microbulbifer thermotolerans, DAU221, Organic solvent-tolerant chitinase, Transglycosylation

\section{Background}

Chitin is a linear $\beta$-1,4-linked homopolymer of $N$-acetyl$\beta$-D-glucosamine (GlcNAc), the second most abundant biomass on earth after cellulose. Chitin is present in the cell walls of fungi and in the exoskeletons of crustaceans and arthropods. Approximately $10^{11}$ tons of chitin is discarded every year $[1,2]$. However, chitin is biocompatible, biodegradable, and bioabsorbable [3]. Commercially,

\footnotetext{
*Correspondence: ylchoi@dau.ac.kr

${ }^{\dagger}$ Hyo-Jung Lee and Yong-Suk Lee contributed equally to this paper Department of Biotechnology, Dong-A University, Busan 49315, Republic of Korea
}

chitin is traditionally degraded with concentrated acids or alkalis. However, there are many issues with these processes, including the production of environmental pollution and acidic waste, low yield, and high cost. Enzymatic hydrolysis of chitin could resolve these problems. Therefore, the development of an enzymatic method of chitin degradation is important [4-8].

Chitinases [EC. 3.2.1.14] are hydrolytic enzymes that degrade the glycosidic bonds between chitin polymers. These enzymes belong to glycosyl hydrolase family 18 (GH 18) and 19 (GH 19) with most chitinases in bacteria, fungi, viruses, animals, plants, and other organisms

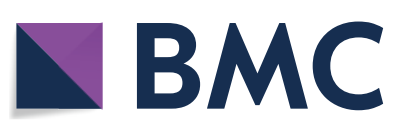

(c) The Author(s) 2018. This article is distributed under the terms of the Creative Commons Attribution 4.0 International License (http://creativecommons.org/licenses/by/4.0/), which permits unrestricted use, distribution, and reproduction in any medium, provided you give appropriate credit to the original author(s) and the source, provide a link to the Creative Commons license, and indicate if changes were made. The Creative Commons Public Domain Dedication waiver (http://creativecommons.org/ publicdomain/zero/1.0/) applies to the data made available in this article, unless otherwise stated. 
being GH18 enzymes $[9,10]$. All GH 18 chitinases have a triosephosphate isomerase fold [TIM $(\beta / \alpha)_{8}$ fold] with a conserved DXXDXDXE motif in the catalytic domain. The TIM $(\beta / \alpha)_{8}$ fold contains $\alpha+\beta$ insertion domain that is associated with deepening of the substrate-binding groove [11]. The deepening of the substrate-binding groove influences enzymatic activity, i.e., processivity. In a previous report on processive cellulases, it was shown that processive chitinases have long substratebinding clefts, or tunnels, as well as substrate-binding clefts $[12,13]$. Processive enzymes have increased catalytic efficiency because the detached polymer chains are prevented from reassociating with crystalline material and stay closely associated with polymer chains [12, 14].

Chitinases can be classified as endochitinases or exochitinases. Endochitinases randomly cleave internal sites in the chitin chain and release GlcNAc and chitooligosaccharides, whereas exochitinases or chitobiosidases (EC 3.2.1.29) catalyze the hydrolysis of chitin polymers from the reducing or non-reducing ends and release chitobiose. 1,4- $\beta-N$-Acetylglucosaminidases [EC 3.2.1.30] cleave chitobiose and release $N$-acetylglucosamine [15-17].

Some chitinases have accessory domains, such as chitin-binding domains (ChBDs), fibronectin type III domains (FN3s), and polycystic kidney disease domains (PKDs). These domains help the chitinase cleave polymeric substrates. In addition, some chitinases have transglycosylation (TG) activity. Through TG, the produced chitooligosaccharide moiety can be transferred to a proper acceptor to make a new glycosidic bond. Furthermore, TG allows chitooligosaccharide with a specific degree of polymerization (DP) to be produced [18]. N-Acetylglucosamine and chitooligosaccharides produced via the hydrolase or TG activity of chitinase have useful functions, including as drug delivery carriers, antioxidants, in hemostasis and wound healing, immuno-enhancers and host defense activation, blood cholesterol control, antibacterial agents for food preservation, elicitors, lysozyme inducers, immunoenhancers, and for natural cancer prevention and treatment $[3,16,19,20]$.

In a previous report, Microbulbifer thermotolerans DAU221 was isolated from the eastern coast of the Republic of Korea, and genomic library of this bacterium was constructed [21]. In this study, we report the characterization of novel chitinase from DAU221. The putative chitinase was cloned, expressed, purified, and characterized, and the results demonstrated that it is a sub-acidic chitinase with transglycosylation activity. The results of this study indicate that the chitinase could be used in extreme industrial conditions.

\section{Materials and methods}

\section{Preparation of colloidal chitin}

Colloidal chitin was prepared by a modification of the method of Roberts and Selitrennikoff [22]. Briefly, $175 \mathrm{~mL}$ of concentrated $\mathrm{HCl}$ was carefully poured onto $10 \mathrm{~g}$ of crab shell (C9213; Sigma-Aldrich, St. Louis, USA) and stirred at $4{ }^{\circ} \mathrm{C}$ for $24 \mathrm{~h}$. Then, $1 \mathrm{~L}$ of ice-cold $95 \%$ ethanol was added to the mixture and stirred at $4{ }^{\circ} \mathrm{C}$ for $12 \mathrm{~h}$. The sediment was harvested by centrifugation at $8000 \mathrm{rpm}$ for $20 \mathrm{~min}$ at $4{ }^{\circ} \mathrm{C}$, and the continually washed with sterile distilled water until the acid was neutralized.

\section{Bacterial strains, plasmids, and culture conditions}

The Microbulbifer thermotolerans DAU221 strain used in this study was deposited in the Korean Culture Center of Microorganisms (KCCM 43021; 16S rDNA sequence GenBank ID: KC571186). It was cultivated in Marine Broth 2216 (MB; Difco, Detroit, MI, USA). Plasmids pUC118 and pCC1FOS (Epicentre, Madison, WI, USA) and Escherichia coli (E. coli) JM109, EPI300-T1 were used to construct the genomic library and cloning the chitinase gene. The pCold I plasmid vector (TaKaRa, Otsu, Japan) and E. coli BL21 (DE3) cells were used for heterologous expression. M. thermotolerans DAU221 was cultured in $\mathrm{MB}$ medium with shaking at $30{ }^{\circ} \mathrm{C}$ overnight. $E$. coli JM109 and BL21 (DE3) were grown in Luria-Bertani (LB) broth at $37^{\circ} \mathrm{C}$. Ampicillin $(50 \mu \mathrm{g} / \mathrm{mL})$ or chloramphenicol $(12.5 \mu \mathrm{g} / \mathrm{mL})$ was added to the LB broth when required. Oligonucleotide primers were purchased from Bioneer (Daejeon, South Korea). Chitooligosaccharides$\mathrm{N}$-acetylglucosamine $\left(\mathrm{NAG}_{1}\right)$, chitobiose $\left(\mathrm{NAG}_{2}\right)$, chitotriose $\left(\mathrm{NAG}_{3}\right)$, chitotetraose $\left(\mathrm{NAG}_{4}\right)$, chitopentaose $\left(\mathrm{NAG}_{5}\right)$, and chitohexaose $\left(\mathrm{NAG}_{6}\right)$-were purchased from Seikagaku (Tokyo, Japan).

\section{Cloning and amino acid sequence analysis of the chitinase from $M$. thermotolerans DAU221}

Microbulbifer thermotolerans DAU221 genomic library was constructed. The library was constructed using a fosmid library construction kit (CopyControl Fosmid Library Production Kit; Epicentre) [21]. The genomic library was cultured on LB agar plates containing $0.2 \%$ $(\mathrm{w} / \mathrm{v})$ colloidal chitin and ampicillin $(50 \mu \mathrm{g} / \mathrm{mL})$ at $37^{\circ} \mathrm{C}$ for 5 days. After incubation, colonies with clear halo zones were chosen as chitinase-producing clones. To make the first subclone, HindIII was used to cut out mtch509, which was ligated into pUC118. Then, the chitinase-producing clone was digested with $\mathrm{Xba \textrm {I }}$ and ligated into pUC118 to make a second subclone. Both of these had chitinase activity, and the sequences were confirmed.

Sequences that are similar to MtCh509 were searched by BLAST (National Center for Biotechnology 
Information, NCBI). The presence of a signal peptide was investigated using the SignalP 3.0 server (http://www.cbs. dtu.dk/services/SignalP) [23]. MtCh509 was aligned with similar sequences using the ClustalW [24] and ESPript 3.0 programs [25]. Three-dimensional (3D) structure of MtCh509 was predicted with Protein Homology/analogY Recognition Engine Ver. 2.0 (Phyre ${ }^{2}$ ) server (http://www. sbg.bio.ic.ac.uk/phyre/) [26].

\section{Expression and purification of recombinant MtCh509}

To express recombinant MtCh509, E. coli BL21 (DE3) cells containing a recombinant plasmid were incubated in LB broth containing $50 \mu \mathrm{g} / \mathrm{mL}$ ampicillin at $37^{\circ} \mathrm{C}$. When the $\mathrm{OD}_{600}$ reached $0.4-0.5$, the cells were incubated on ice for $30 \mathrm{~min}$. Then, IPTG was added to a final concentration of $0.1 \mathrm{M}$, and incubated at $15{ }^{\circ} \mathrm{C}$ for $24 \mathrm{~h}$. The cells were harvested by centrifugation at $6000 \mathrm{rpm}$ for $20 \mathrm{~min}$ at $4{ }^{\circ} \mathrm{C}$. The cells were re-suspended with His-tag binding buffer [20 mM sodium phosphate ( $\mathrm{pH} 7.4), 0.5 \mathrm{M} \mathrm{NaCl}$, $5 \mathrm{mM}$ imidazole]. The cells were lysed by an ultrasonicator with 15-s pulse for three times. The lysed cells were centrifuged $\left(13,000 \mathrm{rpm}\right.$ at $4{ }^{\circ} \mathrm{C}$ for $\left.10 \mathrm{~min}\right)$, and then the supernatant was collected. The recombinant protein was purified with His-Trap HP column (Amersham Biosciences). The column was equilibrated with His-tag binding buffer, and the collected supernatant was loaded on the column. The bound protein was eluted with Histag elution buffer $[20 \mathrm{mM}$ sodium phosphate $(\mathrm{pH} 7.4)$, $0.5 \mathrm{M} \mathrm{NaCl}, 0.5 \mathrm{M}$ imidazole]. The eluted fractions were passed through an Amicon Ultra-4 filter (Millipore, Bedford, MA, USA), and the buffer was changed to $20 \mathrm{mM}$ sodium phosphate ( $\mathrm{pH}$ 7.4).

\section{Determination of protein quantification}

Purified protein was quantified by the Bradford method [27]. Bovine serum albumin (BSA) was used to construct a standard calibration curve.

\section{Determination of molecular weight and zymogram analysis}

The molecular weight of MtCh509 was determined using sodium dodecyl sulfate-polyacrylamide gel electrophoresis (SDS-PAGE) method [28]. The SDS-PAGE gel consisted of a $10 \%$ separating gel and a $5 \%$ stacking gel. The protein size was estimated using standard protein markers (Elpis-Biotech, Daejeon, Korea). After separating the samples, the gel was stained with $0.05 \%$ Coomassie brilliant blue R-250 for $2 \mathrm{~h}$, and then decolorized with de-staining solution (water:methanol:acetic acid glacial $=6: 3: 1$. . To detect chitinase activity, the protein sample was diluted in native page buffer and loaded into a gel containing $0.1 \%$ glycol chitin. After electrophoresis, the gel was incubated in refolding buffer [50 $\mathrm{mM}$ citrate buffer (pH 5.0), $1 \%$ Triton $\mathrm{X}-100$ ] at $50{ }^{\circ} \mathrm{C}$ for $4 \mathrm{~h}$. Then, the gel was stained with $0.01 \%$ calcofluor white M2R in $50 \mathrm{mM}$ citrate buffer ( $\mathrm{pH} \mathrm{5.0)}$ for $2 \mathrm{~h}$. The gel was rinsed several times with distilled water for $1 \mathrm{~h}$ each and visualized on a UV transilluminator [29].

\section{Chitinase activity}

Chitinase activity was measured using a modified dinitrosalicylic acid (DNS) method [30]. The reaction mixture (total volume, $250 \mu \mathrm{L}$ ) contained $50 \mathrm{mM}$ citrate buffer (pH 5.0), 1\% colloidal chitin $(100 \mu \mathrm{L})$, and $3 \mu \mathrm{g}$ of purified enzyme. The reaction mixture was incubated at $55{ }^{\circ} \mathrm{C}$ for $1 \mathrm{~h}$. After the reaction was complete, DNS $(750 \mu \mathrm{L})$ was added to the reaction mixture and boiled for $10 \mathrm{~min}$. Then, the mixture was cooled on ice and centrifuged at 13,000 rpm for $1 \mathrm{~min}$. Reducing sugar was measured as the absorbance at $540 \mathrm{~nm}$. One unit of MtCh509 chitinase activity was defined as the amount of enzyme needed to liberate $1 \mu \mathrm{mol}$ of reducing sugar per minute. $\mathrm{NAG}_{2}$ was used as a standard.

\section{Effect of temperature and $\mathrm{pH}$ on chitinase activity}

To determine the optimum temperature for MtCh509 chitinase activity, chitinase assays were performed at various temperatures $\left(10-80{ }^{\circ} \mathrm{C}\right)$. All other reaction parameters were standard assay conditions. Thermal stability was measured as the residual activity after purified MtCh509 was preincubated at $10-80{ }^{\circ} \mathrm{C}$ for $30 \mathrm{~min}$ before the assay. For the assay, $1 \%$ colloidal chitin was added to the preincubated sample, and the reaction mixture was incubated at the optimum temperature for $1 \mathrm{~h}$. To assess high-temperature stability, the enzyme was preincubated at $40,50,55$, and $60^{\circ} \mathrm{C}$ for up to $4 \mathrm{~h}$ and then incubated at the optimum temperature for $1 \mathrm{~h}$.

The optimum $\mathrm{pH}$ was determined by performing the assay with a variety of buffers at different $\mathrm{pH}$ values (50 mM each): citrate buffer ( $\mathrm{pH} 3.0-6.0)$, sodium phosphate (pH 6.0-8.0), Tris- $\mathrm{HCl}(\mathrm{pH} 8.0-9.0)$, and glycine$\mathrm{NaOH}(\mathrm{pH} 9.0-10.0)$ at the optimum temperature for $1 \mathrm{~h}$. To determine $\mathrm{pH}$ stability, purified MtCh509 was preincubated in the buffers mentioned above for $1 \mathrm{~h}$ on ice. After preincubation, $1 \%$ colloidal chitin $(100 \mu \mathrm{L})$ was added to the mixture, which was incubated at the optimum temperature for $1 \mathrm{~h}$.

\section{Effects of metal ions, chemicals, $\mathrm{NaCl}$, and organic solvents on chitinase activity}

The effect of metal ions and $\mathrm{NaCl}$ was assayed by measuring the residual activity in the presence of each ion or salt. Purified MtCh509 was preincubated with 1, 5, and $10 \mathrm{mM}$ of various metal ions, including $\mathrm{Ba}^{2+}, \mathrm{Ca}^{2+}$, $\mathrm{Co}^{2+}, \mathrm{Cs}^{2+}, \mathrm{Cu}^{2+}, \mathrm{Fe}^{3+}, \mathrm{Hg}^{2+}, \mathrm{K}^{+}, \mathrm{Li}^{+}, \mathrm{Mg}^{2+}, \mathrm{Na}^{+}, \mathrm{Ni}^{+}$, and $\mathrm{Zn}^{2+}$, as well as EDTA and dithiothreitol [DTT] for 
$1 \mathrm{~h}$ on ice. Then, to assess residual activity, $1 \%$ colloidal chitin was added to the mixture and incubated for $1 \mathrm{~h}$ at the optimum temperature and $\mathrm{pH}$. Because EDTA is a metal ion chelator, it was used as a negative control [16]. To determine the effect of salinity on activity, the enzyme was incubated with different concentrations of $\mathrm{NaCl}(0.5$, 1, 1.5, 2, 2.5, 3, 4, and $5 \mathrm{M}$ ). Purified MtCh509 mixed with $\mathrm{NaCl}$ was placed on ice for $30 \mathrm{~min}$. Then, $1 \%$ colloidal chitin was added to the preincubated mixture and incubated under standard assay conditions. The effect of organic solvents on chitinase activity was studied by incubating the enzyme with different solvents, including acetone, butanol, DMSO, ethanol, hexane, isoamyl alcohol, isopropyl alcohol, and methanol. The final concentrations of organic solvents were $10 \%$ and $20 \%(\mathrm{v} / \mathrm{v})$. The reaction mixtures, containing $50 \mathrm{mM}$ citrate buffer (pH 5.0), 1\% colloidal chitin, organic solvent, and purified MtCh509, were incubated at $55^{\circ} \mathrm{C}$ for $1 \mathrm{~h}$. Then, residual activity was measured by the DNS methods.

\section{Substrate specificity and enzyme kinetics of MtCh509}

To determine the substrate specificity of MtCh509, purified MtCh509 was incubated with a variety of substrates under standard assay conditions. The final concentration of each substrate was $1 \%$. The substrates tested were colloidal chitin, glycol chitin, carboxymethyl cellulose (CMC), and Avicel (microcrystalline cellulose). The reducing sugar released in each reaction was measured using the DNS method as mentioned above. The kinetic parameters of MtCh509 chitinase activity were estimated by studying the initial reaction rate of purified MtCh509. Different concentrations of colloidal chitin were used as substrates at final concentration ranges of $2-7 \mathrm{mg} / \mathrm{mL}$. The reaction mixtures were incubated in assay buffer for $10 \mathrm{~min}$. The assay was performed in triplicate. The kinetic constants, $K_{\mathrm{m}}$ and $V_{\max }$, were estimated by a LineweaverBurk plot.

\section{Thin-layer chromatography (TLC) analysis of colloidal chitin and chitooligosaccharides hydrolysates produced by MtCh509}

Reaction mixtures $(25 \mu \mathrm{L})$ containing $1 \%$ colloidal chitin $(10 \mu \mathrm{L})$ and $0.3 \mu \mathrm{L}$ of purified enzyme in $50 \mathrm{mM}$ citrate buffer $(\mathrm{pH} 5.0)$ were incubated at $55{ }^{\circ} \mathrm{C}$ for various times $(0,1,15,30,60,180,360,540$, and $720 \mathrm{~min})$. When chitooligosaccharides $\left(\mathrm{NAG}_{2}-\mathrm{NAG}_{6}\right)$ were used as substrates, the reaction mixtures $(10 \mu \mathrm{L} ; 50 \mathrm{mM}$ citrate buffer, substrate, and purified MtCh509) were incubated at $55^{\circ} \mathrm{C}$ for $1,5,10,15,30$, and $60 \mathrm{~min}$. Then, $1 \mu \mathrm{L}$ of $0.1 \mathrm{M} \mathrm{NaOH}$ was added to stop the reaction. When the reaction was complete, aliquots of the reaction mixtures were separated by TLC on a silica gel plate (Dieselgel 60; Merck, Berlin, Germany) with a solvent system containing $n$-butanol, methanol, $25 \%$ ammonia solution, and water [5:4:2:1 (v:v:v:v)]. The products were detected by spraying the plate with aniline-diphenylamine reagent (4 $\mathrm{mL}$ of aniline, $4 \mathrm{~g}$ of diphenylamine, $200 \mathrm{~mL}$ of acetone, and $30 \mathrm{~mL}$ of $85 \%$ phosphoric acid) and baking it at $180{ }^{\circ} \mathrm{C}$ for $10 \mathrm{~min}$ [31].

\section{High-performance liquid chromatography (HPLC)}

To identify the major products of chitin hydrolysis by MtCh509, an HPLC analysis was performed. Colloidal chitin was used as substrate. Reaction mixtures $(500 \mu \mathrm{L})$ containing colloidal chitin, $50 \mathrm{mM}$ citrate buffer ( $\mathrm{pH} 5.0$ ), and $6 \mu \mathrm{g}$ of MtCh509 were incubated at $55{ }^{\circ} \mathrm{C}$ for $12 \mathrm{~h}$. After incubation, the reaction mixture was centrifuged at $13,000 \mathrm{rpm}$ for $10 \mathrm{~min}$ at $4{ }^{\circ} \mathrm{C}$. Then, the supernatant was filtered through a $0.22-\mu \mathrm{m}$ syringe filter. The filtered reaction mixture was injected into HPLC (Waters 1500 series HPLC system) equipped with an Inertsil an HPLC column $(4.6 \times 250 \mathrm{~mm}, 5 \mu \mathrm{m}$; GL Sciences Inc., Japan $)$. The injection volume was $20 \mu \mathrm{L}$. The column temperature was $40{ }^{\circ} \mathrm{C}$. The mobile phase was composed of $70 \%$ acetonitrile and $30 \%$ MilliQ $\mathrm{H}_{2} \mathrm{O}$, and the flow rate was $1 \mathrm{~mL} / \mathrm{min}$. ELSD was used as the detector and the carrier gas was nitrogen, which was delivered at $20 \mathrm{psi}$. The drift temperature was $50{ }^{\circ} \mathrm{C}$. An equal quantity of chitooligosaccharides $\left(\mathrm{NAG}_{1}-\mathrm{NAG}_{6}\right)$ was used to generate standard peaks.

\section{Results}

\section{Isolation and amino acid analysis of MtCh509}

Chitin degrading clones identified among the fosmid genomic library of $M$. thermotolerans DAU221 were isolated on LB-colloidal chitin agar medium and named $\mathrm{CH} 1-\mathrm{CH} 4$. The $\mathrm{CH} 4$ clone was selected and subcloned into pUC118 for sequencing, resulting in the identification of the chitinase gene, mtch509, from $M$. thermotolerans DAU221. The mtch509 gene is $1527 \mathrm{bp}$ and encodes a protein of 509 amino acids. The deduced amino acid sequence of MtCh509 was compared with those of known bacterial chitinases, which were obtained from the NCBI database. The protein with the highest amino acid sequence identity (71\%) was a chitinase from Simiduia agarivorans (WP_015046629). The next highest sequence similarity (63\%) was to a chitinase from Cellvibrio japonicus (WP_012488573), followed by chitinases from Cellvibrio mixtus (WP_039915554, 60\%), Gilvimarinus agarilyticus (WP_041522559, 56\%), and Saccharophagus degradans (WP_011468184, 55\%). The MtCh509 amino acid sequence contains a glycosyl hydrolase family 18 (GH 18) and chitin-binding domain type 3 (ChtBD3) motifs. The conserved amino acid sequences in the catalytic domain of GH 18 proteins are DXXDXDXE and SXGG, and these sequences are present in MtCh509. 
In addition, a ChtBD3 motif was also observed to be conserved in MtCh509 (AKWWTQ; Fig. 1).

\section{Expression and purification of MtCh509}

The $m t c h 509$ gene was PCR amplified without its signal peptide. The amplicon was cloned into the vector pCold I, such that the resulting plasmid, pCold I-MtCh509, encoded MtCh509 with a 6 histidine tag at the N-terminus. The pCold I-MtCh509 plasmid was transformed in E. coli BL21 (DE3) cells for heterologous protein expression. Cells were incubated with $0.1 \mathrm{M}$ IPTG at $15{ }^{\circ} \mathrm{C}$ for $24 \mathrm{~h}$ after which the cells were disrupted, and the cell lysate containing MtCh509 was collected. The enzyme was purified by His-tag affinity chromatography. An SDS-PAGE analysis under denaturing conditions showed that the molecular weight of MtCh509 was approximately $60 \mathrm{kDa}$. The zymogram results showed a clear zone around a single band (Fig. 2).

\section{Effects of temperature and pH on MtCh509 activity}

To determine the optimum temperature for the chitinase activity of purified MtCh509, the enzyme was incubated at various temperatures $\left(10-80{ }^{\circ} \mathrm{C}\right)$ for $1 \mathrm{~h}$. Purified MtCh509 showed the highest activity at $55^{\circ} \mathrm{C}$. When the maximal activity was set to $100 \%$, MtCh509 showed $\sim 60 \%$ activity at $50{ }^{\circ} \mathrm{C}$ and $55 \%$ activity at $60{ }^{\circ} \mathrm{C}$. When purified MtCh509 was preincubated at $70{ }^{\circ} \mathrm{C}$, the activity decreased sharply to $9 \%$ (Fig. 3a). Next, purified MtCh509 was incubated without substrate for $4 \mathrm{~h}$ at 40 , 50 , and $55^{\circ} \mathrm{C}$, and then assayed for chitinase assay. The results showed that the purified MtCh509 was highly stable for $4 \mathrm{~h}$ at up to $40{ }^{\circ} \mathrm{C}$. In addition, the enzyme was stable at $50{ }^{\circ} \mathrm{C}$ for $2 \mathrm{~h}$ (Fig. $3 \mathrm{~b}$ ).

The effect of $\mathrm{pH}$ on MtCh509 activity was assessed across a broad range of $\mathrm{pH}$ values (3.0-10.0) using $1 \%$ colloidal chitin as a substrate (Fig. 3c). The maximal MtCh509 activity was observed in $50 \mathrm{mM}$ citrate buffer at $\mathrm{pH} 4.6$ and 5.0. This activity was significantly increased at $\mathrm{pH} 4.4$ with more than $80 \%$ activity observed in $50 \mathrm{mM}$ citrate buffer at $\mathrm{pH} 4.4-6.0$. This activity of MtCh509 decreased sharply (to 30\%) in $50 \mathrm{mM}$ sodium phosphate buffer at $\mathrm{pH} 6.0$, increasing to $\sim 80 \%$ at $\mathrm{pH}$ 7.0. Under alkaline conditions, the activity of MtCh509 decreased. MtCh509 exhibited more than 60\% stability in
$50 \mathrm{mM}$ citrate buffer in the sub-acidic range of $\mathrm{pH} 4.2$ 6.0. However, the enzyme exhibited relatively low stability under neutral and alkaline conditions.

\section{Effects of various metals ion, chemical reagents, and $\mathrm{NaCl}$ on MtCh509 activity}

To examine the effects of various metal ions and chemical reagents on MtCh509 activity, the purified recombinant enzyme was preincubated with various metal ions and chemical reagents, including $\mathrm{Ni}^{2+}, \mathrm{Cu}^{2+}, \mathrm{Mg}^{2+}, \mathrm{Li}^{+}$, $\mathrm{Ba}^{2+}, \mathrm{K}^{+}, \mathrm{Zn}^{2+}, \mathrm{Mn}^{2+}, \mathrm{Ca}^{2+}, \mathrm{Co}^{2+}, \mathrm{Cs}^{2+}, \mathrm{Hg}^{2+}$, EDTA, and DTT, for $1 \mathrm{~h}$ on ice without substrate. The final concentrations of metal ions and chemical reagents were 1,5 , or $10 \mathrm{mM}$. Subsequently, the residual activity of MtCh509 was estimated using colloidal chitin as a substrate at $55{ }^{\circ} \mathrm{C}$ for $1 \mathrm{~h}$. In the presence of $1 \mathrm{mM} \mathrm{Ni}^{2+}$, MtCh509 showed $\sim 100 \%$ residual activity decreasing stepwise, in the presence of 5 and $10 \mathrm{mM} \mathrm{Ni}^{2+}$. Relatively high activity was maintained in the presence of $5 \mathrm{mM}$ $\mathrm{Cu}^{2+}$, although the activity dropped sharply in the presence of $10 \mathrm{mM} \mathrm{Cu}^{2+}$. When preincubated with $\mathrm{Mg}^{2+}$, the residual activity of MtCh509 was high in the presence of $1 \mathrm{mM} \mathrm{Mg}^{2+}$ and decreased moderately in 5 and $10 \mathrm{mM}$. MtCh509 activity was maintained at relatively high levels in the presence of $5 \mathrm{mM} \mathrm{Li}^{+}, \mathrm{Ba}^{2+}$, and $\mathrm{K}^{+}$but was moderately inhibited in the presence of $10 \mathrm{mM}$ of these metal ions. Residual activity was relatively high and moderate in the presence of $5 \mathrm{mM} \mathrm{Zn}^{2+}$ and $\mathrm{Co}^{2+}$, respectively, but sharply decreased in the presence of $10 \mathrm{mM}$ of these metals. MtCh509 activity was strongly inhibited at both high and low concentrations of $\mathrm{Cs}^{2+}$, and $\mathrm{Hg}^{2+}$ strongly decreased MtCh509 activity, even at low concentrations. MtCh509 activity was moderately inhibited by $10 \mathrm{mM}$ $\mathrm{Ca}^{2+}, \mathrm{Mn}^{2+}$, and DTT, and EDTA insignificantly inhibited activity at all assayed concentrations (Table 1).

The effect of $\mathrm{NaCl}$ on $\mathrm{MtCh} 509$ was assessed in $50 \mathrm{mM}$ citrate buffer ( $\mathrm{pH}$ 5.0). Briefly, purified MtCh509 was preincubated with various concentrations of $\mathrm{NaCl}(0.5-5 \mathrm{M})$ on ice. Next, residual MtCh509 activity was measured at $55^{\circ} \mathrm{C}$ for $1 \mathrm{~h}$ and was compared to the activity measured under standard assay conditions without a $\mathrm{NaCl}$ preincubation. Approximately $100 \%$ enzyme activity was retained after a preincubation with up to $1 \mathrm{M} \mathrm{NaCl}$, and MtCh509 activity decreased to $\sim 65 \%$ and $\sim 45 \%$ in the presence

\footnotetext{
(See figure on next page.)

Fig. 1 Alignment of the MtCh509 amino acid sequence with other bacterial chitinases. Similar sequences are marked by boxes and identical sequences are highlighted in red. The chitin-binding domain and the SXGG and DXXDXDXE motifs are marked with black, red, and blue lines under the sequences, respectively. The conserved catalytic proton donor is marked with a black inverted triangle. The conserved $a+\beta$ insertion domain is marked with a gray line. Secondary structural elements (i.e., alpha helix [ $\alpha]$, beta sheet $[\beta]$, random coil $[\eta]$, and beta turn $[7]$ ) are marked on the MtCh509 sequence. MtCh509: chitinase from M. thermotolerance DAU221 (WP_06714446); S. aga: glycosyl hydrolase from Simiduia agarivorans (WP_015046629); C. jap: glycosyl hydrolase from Cellvibrio japonicus (WP_012488573); C. mix: glycosyl hydrolase from Cellvibrio mixtus (WP_039915554); G. aga: glycosyl hydrolase from Gilvimarinus agarilyticus (WP_041522559); and S. deg: glycosyl hydrolase from Saccharophagus degradans (WP_011468184)
} 


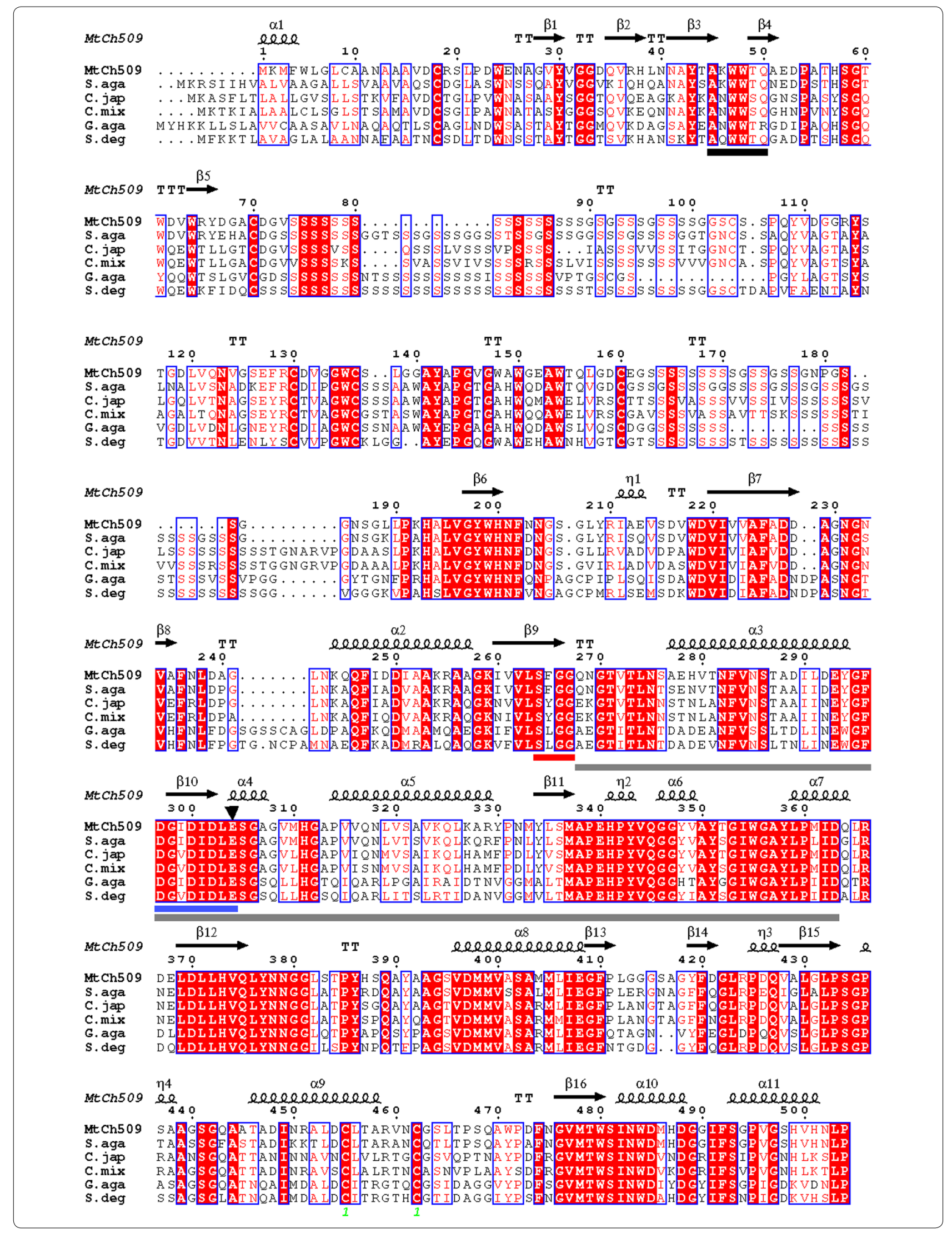




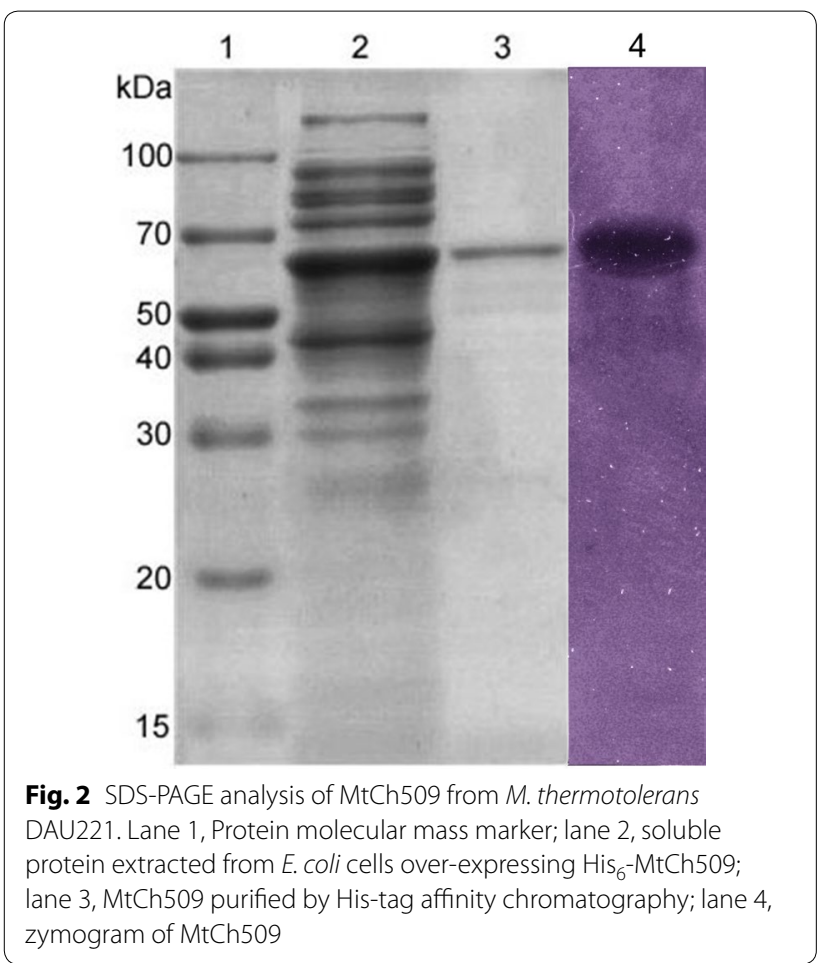

of $2 \mathrm{M} \mathrm{NaCl}$. The activity of MtCh509 decreased as the concentration of $\mathrm{NaCl}$ increased, and $20 \%$ activity was observed in the presence of $5 \mathrm{M} \mathrm{NaCl}$ (Fig. 4).

\section{Effects of various organic solvents on MtCh509 activity}

The effects of solvents on MtCh509 chitinase activity were examined by adding various organic solvents (acetone, butanol, DMSO, ethanol, isoamyl alcohol, isopropyl alcohol, methanol, hexane, benzene, toluene, and acetonitrile) to the standard assay mixture, which was incubated for $1 \mathrm{~h}$ at $55{ }^{\circ} \mathrm{C}$. The activity of MtCh509 was strongly inhibited by acetone, ethanol, and isopropyl alcohol. In the presence of butanol, MtCh509 activity was moderately inhibited, and when $10 \%$ methanol was added, MtCh509 activity was relatively high. In addition, MtCh509 activity rapidly decreased when a high concentration of methanol (20\%) was added. In contrast, MtCh509 activity increased in the presence of DMSO, isoamyl alcohol, hexane, benzene, and toluene to $>100 \%$, and activity reached $\sim 200 \%$ in the presence of $20 \%$ benzene (Table 2).

\section{Substrate specificity and kinetic parameters of MtCh509}

Purified MtCh509 activity was assayed using different substrates with the highest activity observed when glycol chitin was used as a substrate. When colloidal chitin was used as a substrate, MtCh509 activity was slightly lower than that observed with glycol chitin. In the presence of CMC, only weak MtCh509 activity was detected, and no activity was detected with Avicel (Table 3). The kinetic parameters of MtCh509 activity, including $K_{\mathrm{m}}$ and $V_{\max }$, were determined using a Lineweaver-Burk Plot. The calculated $K_{\mathrm{m}}$ and $V_{\max }$ values were $9.275 \mathrm{mg} / \mathrm{mL}$ and $20.4 \mathrm{U} / \mathrm{mg}$, respectively (data not shown).

\section{TLC analysis of the hydrolysates from colloidal chitin and chitooligosaccharides produced by MtCh509}

A TLC analysis was performed to identify the hydrolysis products produced by MtCh509 $(0.3 \mu \mathrm{g})$. The reaction mixture was incubated at $55{ }^{\circ} \mathrm{C}$ for various times (1-720 $\mathrm{min}$ ), and hydrolysate spots were observable after $15 \mathrm{~min}$. The color of the spots increased as time passed. Based on the location of the spots in comparison to the $\mathrm{NAG}_{1-6}$ standard, the primary component of hydrolysate appeared to be $\mathrm{NAG}_{2}$. NAG 1 was also produced as the incubation continued, and a small quantity of $\mathrm{NAG}_{3}$ was produced and then disappeared (Fig. 5A). When chitooligosaccharides were used as the substrate, the major product was also $\mathrm{NAG}_{2}$ (Fig. $5 \mathrm{~B}-\mathrm{E}$ ). In addition, when
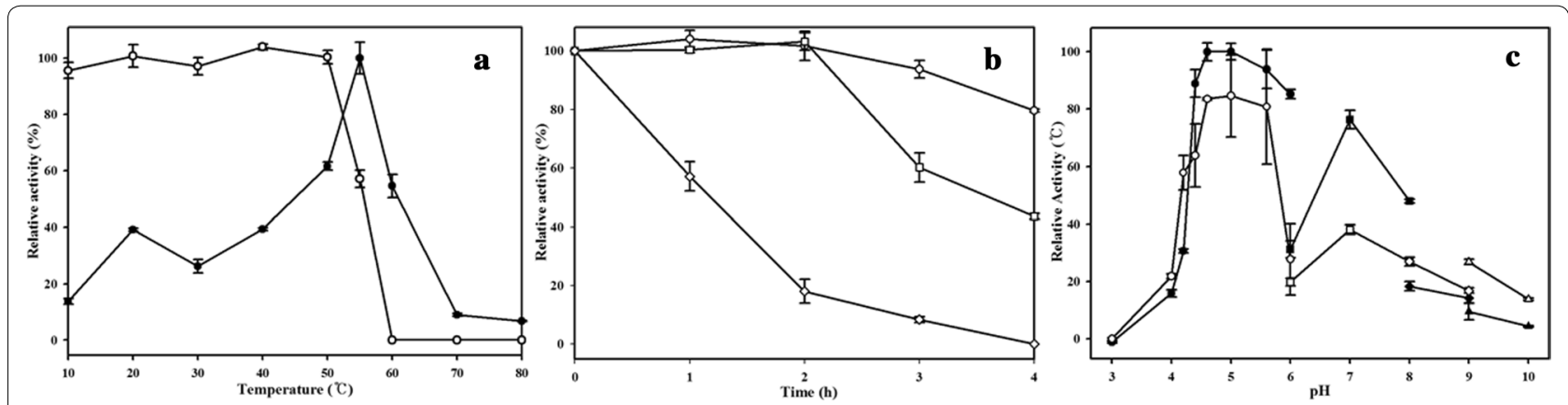

Fig. 3 Effect of temperature, $\mathrm{pH}$, and $\mathrm{NaCl}$ on MtCh509. a Optimal temperature (solid circles) and thermostability (open circles) of MtCh509 under preincubation for $30 \mathrm{~min}$. b Further thermostability of MtCh509 preincubated at $40^{\circ} \mathrm{C}$ (open circles), $50^{\circ} \mathrm{C}$ (open squares), and $55^{\circ} \mathrm{C}$ (open diamonds) for 1-4 h. c Optimal pH (solid) and pH stability (open) of MtCh509. Reactions were performed in the following $50 \mathrm{mM}$ buffers: citrate buffer for pH 3.0-6.0 (circles), sodium phosphate buffer for pH 6.0-8.0 (squares), Tris-HCl buffer for pH 8.0-9.0 (diamonds), and glycine-NaOH buffer for $\mathrm{pH} 9.0-10.0$ (triangles). The means of the relative values $(n=3)$ and standard deviations are shown 
Table 1 Effect of different metal ions and chemical reagents on MtCh509

\begin{tabular}{llll}
\hline Substances & \multicolumn{3}{l}{ Relative activity (\%) } \\
\cline { 2 - 4 } & $\mathbf{1} \mathbf{~ m M}$ & $\mathbf{5} \mathbf{~ m M}$ & $\mathbf{1 0 ~} \mathbf{~ M}$ \\
\hline Control & 100 & 100 & 100 \\
$\mathrm{Ni}^{2+}$ & $100 \pm 5.8$ & $69 \pm 6.9$ & $32 \pm 1.8$ \\
$\mathrm{Cu}^{2+}$ & $99 \pm 5.6$ & $91 \pm 4.9$ & $6 \pm 1.8$ \\
$\mathrm{Mg}^{2+}$ & $93 \pm 5.2$ & $67 \pm 6.9$ & $66 \pm 3.9$ \\
$\mathrm{Li}^{+}$ & $86 \pm 6.3$ & $85 \pm 1.6$ & $67 \pm 7.4$ \\
$\mathrm{Ba}^{2+}$ & $81 \pm 1.0$ & $82 \pm 0.4$ & $73 \pm 1.3$ \\
$\mathrm{~K}^{+}$ & $82 \pm 2.8$ & $84 \pm 0.9$ & $50 \pm 3.4$ \\
$\mathrm{Zn}^{2+}$ & $87 \pm 0.8$ & $77 \pm 0.0$ & $20 \pm 0.6$ \\
$\mathrm{Mn}^{2+}$ & $66 \pm 3.2$ & $49 \pm 0.9$ & $50 \pm 1.1$ \\
$\mathrm{Ca}^{2+}$ & $59 \pm 2.5$ & $51 \pm 1.6$ & $51 \pm 6.0$ \\
$\mathrm{Co}^{2+}$ & $58 \pm 2.6$ & $52 \pm 1.6$ & $25 \pm 2.0$ \\
$\mathrm{Cs}^{2+}$ & $40 \pm 2.0$ & $37 \pm 5.3$ & $48 \pm 3.1$ \\
$\mathrm{Hg}^{2+}$ & $7 \pm 0.5$ & N.D. & N.D. \\
$\mathrm{EDTA}^{2+}$ & $92 \pm 7.3$ & $90 \pm 5.0$ & $82 \pm 2.2$ \\
$\mathrm{DTT}$ & $52 \pm 3.5$ & $59 \pm 1.8$ & $67 \pm 2.3$ \\
\hline
\end{tabular}

\pm , standard error; ND, not detected

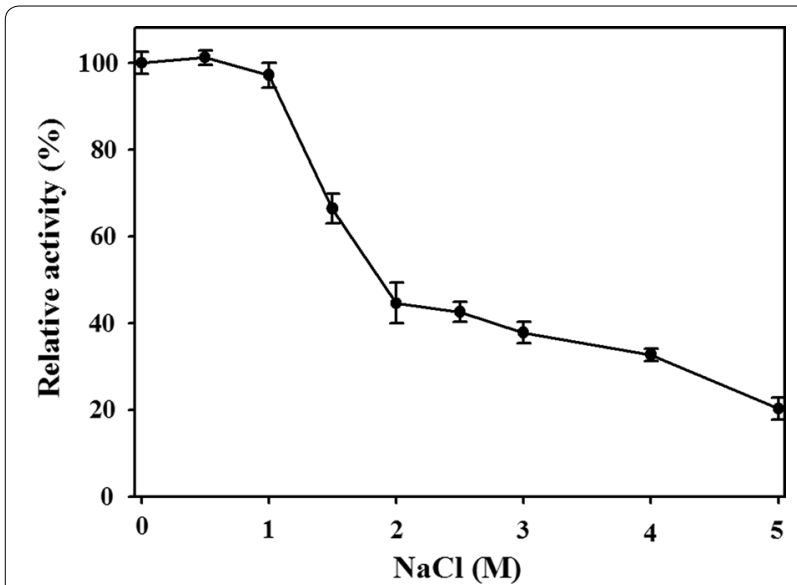

Fig. 4 Effect of $\mathrm{NaCl}$ on MtCh509. MtCh509 was preincubated on ice for 30 min with various concentrations of $\mathrm{NaCl}(0.5-5 \mathrm{M})$. The negative control was a reaction performed in $50 \mathrm{mM}$ citrate buffer ( $\mathrm{pH} 5.0$ ) at $55^{\circ} \mathrm{C}$ without $\mathrm{NaCl}$. The means of the relative values $(n=3)$ and standard deviations are shown

more purified MtCh509 $(0.6 \mu \mathrm{g})$ was used, low amounts of $\mathrm{NAG}_{3}$ were converted to $\mathrm{NAG}_{4}$ (Fig. $5 \mathrm{~F}$ ). This result was not observed when other chitooligosaccharides were used as the substrate (data not shown).

\section{HPLC analysis of the hydrolysate produced by MtCh509}

A reaction mixture using colloidal chitin as a substrate was incubated for $12 \mathrm{~h}$ at $55{ }^{\circ} \mathrm{C}$ and the resulting reaction products were analyzed with a Waters 1500
Table 2 Effect of various organic solvents on MtCh509 from $M$. thermotolerans DAU221

\begin{tabular}{llll}
\hline Solvent & Log $\boldsymbol{P}_{\text {ow }}$ & \multicolumn{2}{c}{ Relative activity (\%) } \\
\cline { 3 - 4 } & & $\mathbf{1 0 \% ( \mathbf { v } / \mathbf { v } )}$ & $\mathbf{2 0 \% ( \mathbf { v } / \mathbf { v } )}$ \\
\hline Control & - & 100 & 100 \\
DMSO & -1.35 & $139 \pm 0.4$ & $158 \pm 9.2$ \\
Methanol & -0.76 & $84 \pm 2.7$ & $9 \pm 1.1$ \\
Acetone & -0.24 & $31 \pm 3.0$ & $9 \pm 0.5$ \\
Ethanol & -0.24 & $44 \pm 2.1$ & $19 \pm 0.8$ \\
Acetonitrile & -0.34 & $20 \pm 0.6$ & $6 \pm 0.2$ \\
Isopropyl alcohol & 0.16 & $33 \pm 0.0$ & $16 \pm 0.9$ \\
Butanol & 0.80 & $74 \pm 3.2$ & $77 \pm 8.0$ \\
Isoamyl alcohol & 1.28 & $127 \pm 4.1$ & $103 \pm 6.4$ \\
Benzene & 2.13 & $148 \pm 29.0$ & $201 \pm 7.1$ \\
Toluene & 2.40 & $165 \pm 5.0$ & $157 \pm 17.5$ \\
Hexane & 3.50 & $139 \pm 12.5$ & $173 \pm 29.5$ \\
\hline
\end{tabular}

\pm , standard error

Table 3 Substrate specificities of the purified MtCh509 from $M$. thermotolerans DAU221

\begin{tabular}{lll}
\hline Substrate & $\begin{array}{l}\text { Specific activity } \\
\text { (U/mg) }\end{array}$ & Relative activity (\%) \\
\hline Colloidal chitin & 34.256 & 100 \\
Glycol chitin & 40.233 & $117.4 \pm 1.5$ \\
Carboxymethyl cellulose & 0.503 & $1.46 \pm 1.4$ \\
Avicel & ND & ND \\
\hline
\end{tabular}

\pm , standard error; ND, not detected

series HPLC system. The six peaks from left to right are $\mathrm{NAG}_{1}-\mathrm{NAG}_{6}$ (Fig. 6a). The second chromatogram shows the hydrolysate peaks produced from colloidal chitin (Fig. 6b). The peaks marked with black and empty arrows are citrate buffer and $\mathrm{NAG}_{3}$, respectively, with the latter peak appearing to be weak. The peak marked with the red arrow is $\mathrm{NAG}_{1}$, which is present in small amounts. Because the $\mathrm{NAG}_{2}$ peak in the hydrolysate is the highest, the major product of colloidal chitin hydrolysis is $\mathrm{NAG}_{2}$.

\section{Discussion}

In this study, we cloned, expressed, and characterized a chitinase from M. thermotolerans DAU221, MtCh509. M. thermotolerans DAU221 was isolated on the eastern coast of the Republic of Korea [21], and it was subsequently shown to express various proteins, including a carbohydrate esterase [21], a maltotriose-producing $\alpha$-amylase [32], and an esterase [33]. Recently, the whole genome sequence of DAU221 was completed [34]. In this 


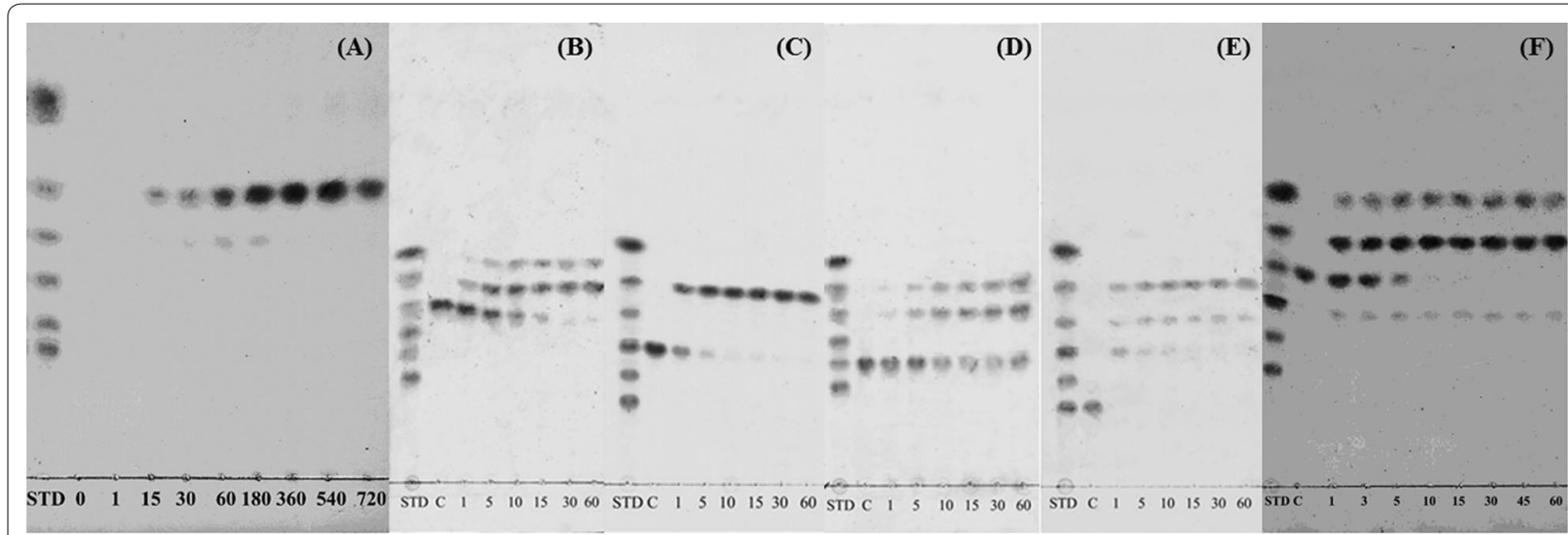

Fig. $5 \mathrm{TLC}$ analysis of the hydrolysis products of colloidal chitin and chitooligosaccharide $\left(\mathrm{NAG}_{3}-\mathrm{NAG}_{6}\right)$ generated by purified MtCh509. The reaction mixture $(25 \mu \mathrm{L})$, which contained $0.3 \mu \mathrm{g}$ of purified $\mathrm{MtCh} 509,50 \mathrm{mM}$ citrate buffer ( $\mathrm{pH} 5.0)$, and substrates, was incubated at $55^{\circ} \mathrm{C}$ for various times (0, 1, 15, 30, 60, 180, 360, 540, or $720 \mathrm{~min}$ ). $\mathbf{A}$ Colloidal chitin was used as a substrate; $\mathbf{B} \mathrm{NAG}_{3}$ was used as a substrate; $\mathbf{C}$ NAG 4 was used as a substrate; $\mathbf{D} N A G_{5}$ was used as a substrate; $\mathbf{E ~ N A G}_{6}$ was used as a substrate; $\mathbf{F} N \mathrm{NG}_{3}$ was used as a substrate and reacted using $0.6 \mu \mathrm{g}$ of purified MtCh509. Lane STD is a standard mixture of $N A G_{1}-N_{A}$. Lane $C$ is a substrate control without purified MtCh509

study, a chitinase from M. thermotolerans DAU221 was studied for the first time.

In marine environments, most chitin originates from phytoplankton. Chitin is utilized by native microorganisms as carbon and nitrogen sources and a number of bacteria produce chitinases [35-38]. The products of chitinase-mediated chitin hydrolysis, $\mathrm{N}$-acetylglucosamine and chitooligosaccharides, have multiple applications, including in solutions for environmental problems, as antimicrobial or insecticidal agents for the biocontrol of plant pathogens [16], and in physiological processes such as nutritional morphogenesis, pathogenesis [39], parasitism, growth regulation, defense, and immunity $[15,40$, 41].

The amino acid sequence of MtCh509 was observed to be similar to that of glycosyl hydrolases from Simiduia agarivorans (71\%), Cellvibrio japonicus (63\%), Cellvibrio mixtus (60\%), Gilvimarinus agarilyticus (56\%), and Saccharophagus degradans (55\%) (Fig. 1). The catalytic domain of GH18 enzymes (DXXDXDXE) is conserved across bacteria, fungi, and archaea [42-46], and MtCh509 contains these conserved DXXDXDXE and SXGG motifs (Fig. 1). The consensus sequence of the carbohydrate-binding module (CBM5) is AKWWTK in bacteria [42], and this sequence was observed to be moderately conserved in MtCh509 $\left(\mathrm{A}^{50} \mathrm{KWWTQ}{ }^{55}\right)$ (Fig. 1). CBM5 can bind substrates through hydrophobic interactions between the aromatic residues of the enzyme and sugar molecules of the substrate [42]. MtCh509 belongs to $\mathrm{GH}$ family 18 , and it has a catalytic domain containing a TIM-barrel $(\beta / \alpha)_{8}$ fold. A comparison of the MtCh509 amino acid sequence to those of SpChiA, SpChiB, and SpChiC from Serratia proteamaculans 568 [47] revealed that the $\alpha / \beta$ fold insertion in MtCh509 was similar to that in SpChiB. SpChiC lacks the $\alpha / \beta$ fold insertion between $\beta$-sheets 7 and 8 in the TIM-barrel fold. The $\alpha+\beta$ insertion leads to a deepening of the substrate-binding groove in the GH family 18 chitinases [11], which may improve enzyme processivity.

MtCh509 was heterologously expressed and purified from E. coli BL21 (DE3) without its signal peptide (Fig. 2). Temperature and $\mathrm{pH}$ are known to have significant effects on enzyme stability and activity [16]. Typically, chitinases have an optimum temperature of $20-50{ }^{\circ} \mathrm{C}$ and are stable up to $55^{\circ} \mathrm{C}[48,49]$. The purified recombinant $\mathrm{MtCh} 509$ showed optimal activity at $55^{\circ} \mathrm{C}$ in $50 \mathrm{mM}$ citrate buffer (pH 5.0) (Fig. 3), which is similar to that reported for chitinases from Massilia timonae [50], P. barengoltzii [49], and B. licheniformis SK-1 [51]. Generally, chitinases are stable at up to $50{ }^{\circ} \mathrm{C}$ [5255], and MtCh509 maintained $~ 100 \%$ enzymatic activity at $50{ }^{\circ} \mathrm{C}$ for up to $2 \mathrm{~h}$. The activity of MtCh509 was slightly lower at $40{ }^{\circ} \mathrm{C}$, and MtCh509 exhibited 80\% activity after incubating for $4 \mathrm{~h}$. MtCh509 activity was moderately decreased when incubated for $2 \mathrm{~h}$ at $50{ }^{\circ} \mathrm{C}$, and $50 \%$ activity was reached before $4 \mathrm{~h}$ (Fig. 3b). A chitinase from Aeromonas veronii, ChiB565, is also stable at up to $50{ }^{\circ} \mathrm{C}$ [56]. Purified MtCh509 showed high activity under sub-acidic conditions, with activity dramatically increased at $\mathrm{pH} 4.4$, and maximal activity was observed at pH 4.6 and 5.0 (Fig. 3c). The optimal $\mathrm{pH}$ of MtCh509 is comparable to that of the bacterial 

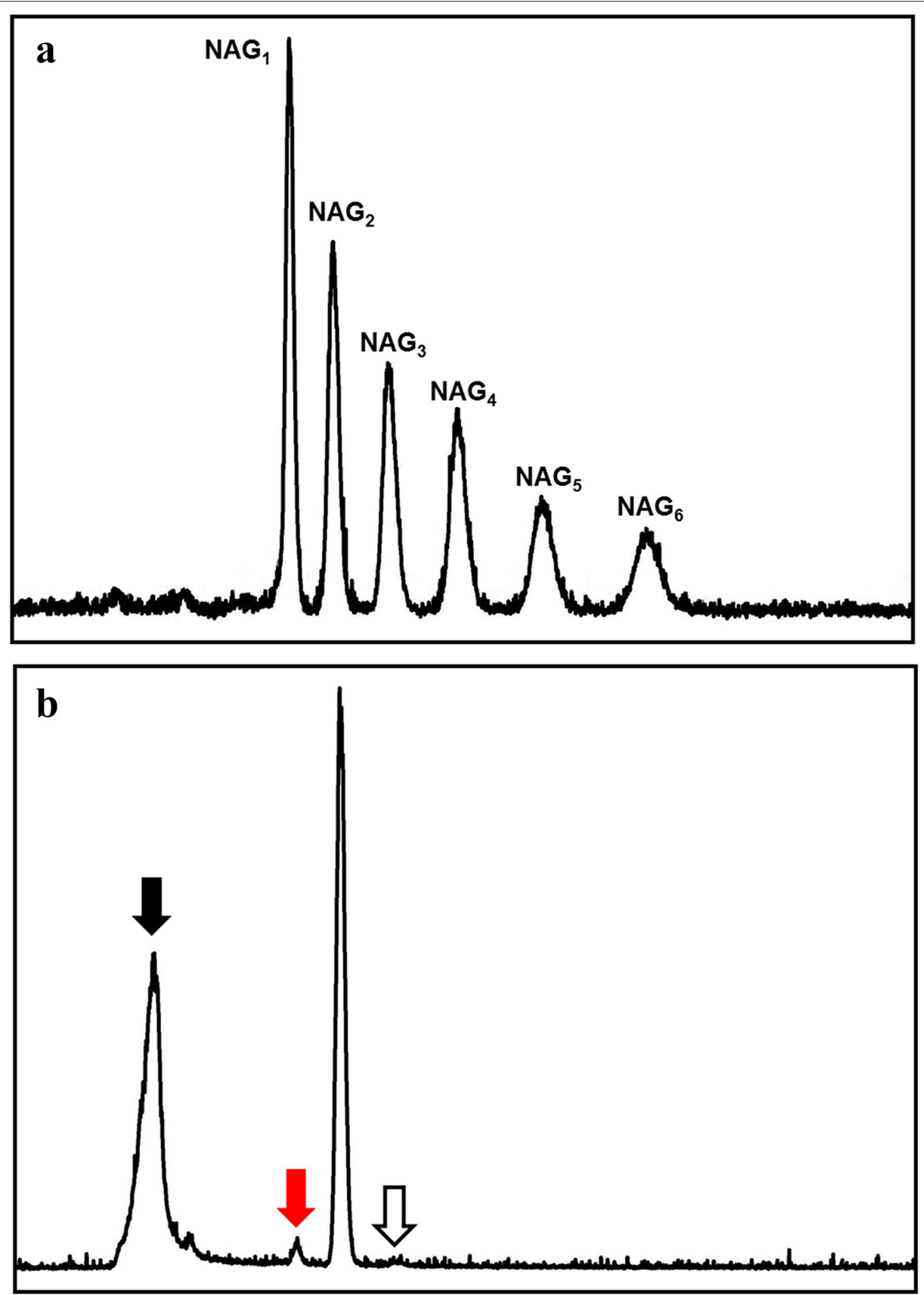

Fig. $6 \mathrm{HPLC}$ analysis of the hydrolysate of colloidal chitin generated by purified MtCh509. a Standard peaks of NAG ${ }_{1}-\mathrm{NAG}_{6}$. b Hydrolysate of colloidal chitin generated by purified MtCh509 (black arrow, buffer; red arrow, NAG; ; white arrow, $\mathrm{NAG}_{3}$ ). The reaction mixture $(500 \mu \mathrm{L})$, which contained $6 \mu \mathrm{g}$ of purified MtCh509, $50 \mathrm{mM}$ citrate buffer ( $\mathrm{pH}$ 5.0), and $1 \%$ colloidal chitin, was incubated at $55^{\circ} \mathrm{C}$ for $12 \mathrm{~h}$ 
chitinases from M. timonae (pH 5.0) [50], Paenibacillus sp. D1 (pH 5.0) [57], and Sanguibacter sp. (pH 4.6) [58]. Purified MtCh509 was stable at sub-acidic $\mathrm{pH}$ values and showed moderate to weak activity under neutral and alkaline conditions. The acidic chitinase from Microbispora sp. [59] showed similar activities.

Marine microorganisms are tolerant to high salt concentrations, and salt-resistant enzymes are vital to industrial processes that require high-salt conditions [16]. The results of our study showed that MtCh509 is a salt-tolerant chitinase, as it maintained a high level of activity at $\mathrm{NaCl}$ concentrations of up to $1 \mathrm{M} \mathrm{NaCl}$. At $1.5 \mathrm{M} \mathrm{NaCl}$, activity decreased to $65 \%$, and at $2 \mathrm{M} \mathrm{NaCl}$, the residual activity was $\sim 40 \%$. Then, activity only slightly reduced in $5 \mathrm{M} \mathrm{NaCl}$ to $20 \%$ (Fig. 4). In comparison, a chitinase from Halobacterium salinarum CECT showed maximal activity at $1.5 \mathrm{M} \mathrm{NaCl}$ [42].

Metal ions can affect enzyme complex formation, the maintenance/destruction of three-dimensional protein structure, and enzyme stability and activity [60]. $\mathrm{Hg}^{2+}$ is known to be a major inhibitor of chitinase activity. It reacts with cysteine residues, specifically in -SH groups, and can change the tertiary structure of a protein [16]. $\mathrm{Hg}^{2+}$ strongly reduced the activation of MtCh509, even at low concentrations (Table 1). Many bacterial chitinases, such as those of Bacillus sp. DAU101 [6], Penicillium ochrochloron MTCC 517 [61], and Pseudoalteromonas tunicata CCUG 44952T [62] were strongly inhibited by $\mathrm{Hg}^{2+} \cdot \mathrm{Cu}^{2+}$ catalyzes the formation of intramolecular $\mathrm{S}-\mathrm{S}$ bridges through auto-oxidation as well as the formation of sulfenic acid [16]. $\mathrm{Cu}^{2+}$ (at $10 \mathrm{mM}$ ) decreased the activity of purified MtCh509. Similarly, a chitinase from Chitinibacter sp. GC72 was highly inhibited by $\mathrm{Cu}^{2+}[63]$. In contrast, another chitinase was observed to be stimulated by $\mathrm{Cu}^{2+}$, as the Asp and Glu in the chitinase active site binds $2^{+}$ions [64]. According to previous reports, $\mathrm{Ca}^{2+}$ generally increases the activity of chitinases from various bacteria, including Chitinibacter sp. GC72 [63] and Bacillus sp. Hu1 [65]. DTT promotes the destruction of S-S bridges in enzymes, and DTT moderately inhibited MtCh509 activity. This result is comparable to that reported for a chitinase from Bacillus licheniformis $\mathrm{Mb}-2$ [66]. EDTA binds to metal ions in solution and acts as a chelating agent, and this compound has been reported to reduce the activity of chitinases produced by Bacillus sp. [65] and Streptomyces sp. [16].

Organic solvents are divided into two categories, nonpolar solvents and polar solvents, which include both polar aprotic solvents and polar protic solvents. In our study, we tested the effects of various organic solvents on the chitinase activity of MtCh509, including acetone, butanol, DMSO, ethanol, isoamyl alcohol, isopropyl alcohol, methanol, hexane, benzene, toluene, and acetonitrile.
Some organic solvents (acetone, ethanol, isopropyl alcohol, and acetonitrile) strongly inhibited chitinase activity, whereas others (DMSO, isoamyl alcohol, hexane, benzene, and toluene) enhanced enzyme activity (Table 2). The level of activation for purified MtCh509 was higher than that reported for other bacterial chitinases from $A$. hydrophila SBK1 [41] and Streptomyces sp. [16]. Most tested non-polar solvents enhanced the activity of purified MtCh509. These results suggest that hydrophobic interactions contribute to the activation of MtCh509 [16].

To identify the best substrate for MtCh509, the chitinase activity of purified MtCh509 was assayed using different substrates (colloidal chitin, glycol chitin, CMC, and Avicel). The highest activity was observed when glycol chitin was used as a substrate. Compared to glycol chitin, colloidal chitin was hydrolyzed much less $(\sim 17 \%)$. However, the specific activity of purified MtCh509 with colloidal chitin as a substrate was higher than that reported for other chitinases $[6,67]$. Very weak activity was observed when $\mathrm{CMC}$ was used as a substrate. Similar to ChiB from Aeromonas veronii B565, MtCh509 also did not hydrolyze CMC as a substrate [56], and no chitinase activity was detected in the presence of Avicel. Similarly, SmChiA did not bind to Avicel [18].

The $K_{\mathrm{m}}$ and $V_{\max }$ values of MtCh509 for colloidal chitin were $9.275 \mathrm{mg} / \mathrm{mL}$ and $20.4 \mathrm{U} / \mathrm{mg}$, respectively. The $K_{\mathrm{m}}$ values of chitinases from other microorganisms were $12.62 \mathrm{mg} / \mathrm{mL}$ [68], $47.92 \mathrm{mg} / \mathrm{mL}$ for SmChiD of Serratia marcescens GPS5 [69], and $35.12 \mathrm{mg} / \mathrm{mL}$ for SpChiD of Serratia proteamaculans [70]. MtCh509 showed a higher affinity toward colloidal chitin than the other tested substrates. The measured $V_{\max }$ of MtCh509 is higher than that reported for several bacterial chitinases, including those from Pseudoalteromonas sp. DL-6 (13.51 U/mg) [71], Streptomyces violaceusniger $(6.6 \mathrm{U} / \mathrm{mg})$ [72], and Bacillus licheniformis SK-1 (7.03 U/mg) [51].

Hydrolysates were analyzed from the reaction using colloidal chitin and $\mathrm{NAG}_{2}-\mathrm{NAG}_{6}$ chitooligosaccharides as substrates (Fig. 5). When colloidal chitin was used as the substrate (Figs. 5A, 6), $\mathrm{NAG}_{1}-\mathrm{NAG}_{3}$ appeared as products. The major product generated by MtCh509 $(0.3 \mu \mathrm{g})$ was $\mathrm{NAG}_{2}$. Many bacterial chitinases have also produced similar results [1, 38, 54]. MtCh509 did not hydrolyze $\mathrm{NAG}_{2}$ (data not shown), suggesting that MtCh509 could not use $\mathrm{NAG}_{2}$ as a substrate. Similarly, $S p$ chitinases ( $S p$ ChiA, $S p$ ChiB, and $S p$ ChiC) from Serratia proteamaculans 568 [47] and FbalChil8A and MvarChi18A from Ferrimonas balearica and Microbulbifer variabilis [43] also could not use $\mathrm{NAG}_{2}$ as a substrate. $\mathrm{NAG}_{3}$ (Fig. 5B) was degraded by MtCh509 to $\mathrm{NAG}_{2}$ and $\mathrm{NAG}_{1}$ within 15 min. $\mathrm{NAG}_{4}$ (Fig. $5 \mathrm{C}$ ) was degraded to $\mathrm{NAG}_{2}$, and $\mathrm{NAG}_{5}$ (Fig. 5D) was degraded to $\mathrm{NAG}_{3}$ and $\mathrm{NAG}_{2} . \mathrm{NAG}_{6}$ (Fig. 5E) was finally degraded to $\mathrm{NAG}_{3}$ and 
$\mathrm{NAG}_{2}$ with $\mathrm{NAG}_{4}$ observed as an intermediate product. Based on these results, we concluded that MtCh509 from $M$. thermotolerans DAU221 is a processive endochitinase. ChiA from Bacillus licheniformis DSM8785 [67] and Sp chitinases (Sp ChiA, $S p \mathrm{ChiB}$, and $S p \mathrm{ChiC}$ ) from Serratia proteamaculans 568 [47] showed similar hydrolysis patterns. In particular, when the levels of purified MtCh509 were high $(0.6 \mu \mathrm{g}), \mathrm{NAG}_{4}$ was synthesized from $\mathrm{NAG}_{3}$, as a substrate (Fig. 5F). This result showed MtCh509 has transglycosylation activity. Under other reaction conditions, such as changing substrates, this result was not observed. Many bacterial transglycosylating chitinases have been reported, including ChiA and ChiB from Serratia marcescens [73], SpChiD from Serratia proteamaculans [74], StmChiA from Stenotrophomonas maltophilia [18], and VhChiA from Vibrio harveyi [75].

In conclusion, an approximately $60 \mathrm{kDa}$ chitinase from M. thermotolerans DAU221 (MtCh509) was heterologously expressed in E. coli and purified by His-tag affinity chromatography. The recombinant protein was stable under sub-acidic conditions and at high temperatures and was highly active in the presence of $1 \mathrm{M} \mathrm{NaCl}$, tolerating up to $5 \mathrm{M} \mathrm{NaCl}$. In addition, MtCh509 interacts with several non-polar organic solvents, presumably through hydrophobic interactions. MtCh509 shows specificity for colloidal chitin with crystalline polysaccharides. Based on amino acid sequence and TLC analyses, MtCh509 is an endochitinase. In addition, MtCh509 has transglycosylation activity and produces $\mathrm{NAG}_{4}$ from $\mathrm{NAG}_{3}$. Thus, MtCh509 can be used for various biotechnological applications.

\section{Authors' contributions}

HYL carried out the experiments and drafted the manuscript; YSL designed the experiments and revised the manuscript. YLC proofed the manuscript. All authors read and approved the final manuscript.

\section{Acknowledgements}

This work was supported by the Dong-A University Research Fund.

\section{Competing interests}

The authors declare that they have no competing interests.

\section{Publisher's Note}

Springer Nature remains neutral with regard to jurisdictional claims in published maps and institutional affiliations.

Received: 6 August 2018 Accepted: 24 October 2018

Published online: 08 November 2018

\section{References}

1. Andronopoulou E, Vorgias CE. Multiple components and induction mechanism of the chitinolytic system of the hyperthermophilic archaeon Thermococcus chitonophagus. Appl Microbiol Biotechnol. 2004;65(6):694-702.

2. Kim TI, Ki KS, Lim DH, Vijayakumar M, Park SM, Choi SH, Kim KY, Im SK, Park BY. Novel Acinetobacter parvus HANDI 309 microbial biomass for the production of $\mathrm{N}$-acetyl- $\beta$-D-glucosamine (GlcNAc) using swollen chitin substrate in submerged fermentation. Biotechnol Biofuels. 2017;10:59.

3. Khoushab F, Yamabhai M. Chitin research revisited. Mar Drugs. 2010;8(7):1988-2012.

4. Il'ina AV, Zueva OY, Lopatin SA, Varlamov VP. Enzymatic hydrolysis of a-chitin. Appl Biochem Microbiol. 2004;40(1):35-8.

5. Sashiwa H, Fujishima S, Yamano N, Kawasaki N, Nakayama A, Muraki E, Hiraga K, Oda K, Aiba SI. Production of N-acetyl-D-glucosamine from a-chitin by crude enzymes from Aeromonas hydrophila H-2330. Carbohydr Res. 2002;337(8):761-3.

6. Lee YS, Park IH, Yoo JS, Chung SY, Lee YC, Cho YS, Ahn SC, Kim CM, Choi YL. Cloning, purification, and characterization of chitinase from Bacillus sp. DAU101. Bioresour Technol. 2007;98(14):2734-41.

7. Hammami I, Siala R, Jridi M, Ktari N, Nasri M, Triki MA. Partial purification and characterization of chi $1 \mathrm{O} 8$, a novel antifungal chitinase produced by Bacillus cereus IO 8. J Appl Microbiol. 2013:115(2):358-66.

8. Ilangumaran G, Stratton G, Ravichandran S, Shukla PS, Potin P, Asiedu S, Prithiviraj B. Microbial degradation of lobster shells to extract chitin derivatives for plant disease management. Front Microbiol. 2017;8:781.

9. Henrissat B, Bairoch A. New families in the classification of glycosyl hydrolases based on amino acid sequence similarities. Biochem $\mathrm{J}$. 1993;293(Pt3):781-8.

10. Nguyen STC, Freund HL, Kasanjian J, Berlemont R. Function, distribution, and annotation of characterized cellulases, xylanases, and chitinases from CAZy. Appl Microbiol Biotechnol. 2018;102(4):1629-37.

11. Suzuki K, Taiyoji M, Sugawara N, Nikaidou N, Henrissat B, Watanabe T. The third chitinase gene (chiC) of Serratia marcescens 2170 and the relationship of its product to other bacterial chitinase. Biochem J. 1999;343(Pt 3):587-96.

12. Divne C, Stahlberg J, Reinikainen T, Ruohonen L, Pettersson G, Knowles $J \mathrm{~K}$, Teeri TT, Jones TA. The three-dimensional crystal structure of the catalytic core of cellobiohydrolase I from Trichoderma reesei. Science. 1994:265(5171):524-8.

13. Rouvinen J, Bergfors T, Teeri T, Knowles JK, Jones TA. Three-dimensional structure of cellobiohydrolase II from Trichoderma reesei. Science. 1990;249(4967):380-6.

14. Horn SJ, Sørbotten A, Synstad B, Sikorski P, Sørlie M, Vårum KM, Eijsink VG. Endo/exo mechanism and processivity of family 18 chitinases produced by Serratia marcescens. FEBS J. 2006;273(3):491-503.

15. Hamid R, Khan MA, Ahmad M, Ahmad MM, Abdin MZ, Musarrat J, Javed S. Chitinases: an update. J Pharm Bioallied Sci. 2013;5(1):21-9.

16. Karthik N, Binod P, Pandey A. Purification and characterisation of an antifungal chitinase produced by a Streptomyces sp. Bioresour Technol. 2015;188:195-201.

17. Zhang R, Zhou J, Song Z, Huang Z. Enzymatic properties of $\beta-N-$ acetylglucosaminidase. Appl Microbiol Biotechnol. 2018;102(1):93-103.

18. Suma K, Podile AR. Chitinase A from Stenotrophomonas maltophilia shows transglycosylation and antifungal activities. Bioresour Technol. 2013;133:213-20

19. Dahiya N, Tewari R, Hoondal GS. Biotechnological aspects of chitinolytic enzymes: a review. Appl Microbiol Biotechnol. 2006;71(6):773-82.

20. Uni F, Lee S, Yatsunami R, Fukui T, Nakamura S. Role of exposed aromatic residues in substrate-binding of CBM family 5 chitin-binding domain of alkaline chitinase. Nucleic Acids Symp Ser. 2009;53:311-2.

21. Lee YS, Heo JB, Lee JH, Choi YL. A cold-adapted carbohydrate esterase from the oil-degrading marine bacterium Microbulbifer thermotolerans DAU221: gene cloning, purification, and characterization. J Microbiol Biotechnol. 2014;24(7):925-35.

22. Roberts WK, Selitrennikoff CP. Plant and bacterial chitinases differ in antifungal activity. J Gen Microbiol. 1988;134:169-76.

23. Peterson TN, Brunak S, von Heijne G, Nielsen H. SignalP 4.0: discriminating signal peptides from transmembrane regions. Nat Methods. 2011;8(10):785-6.

24. Thompson JD, Higgins DG, Gobson TJ. CLUSTAL W: improving the sensitivity of progressive multiple sequence alignment through sequence weighting, positions-specific gap penalties and weight matrix choice. Nucleic Acids Res. 1994;22(22):4673-80.

25. Robert $X$, Gouet P. Deciphering key features in protein structures with the new ENDscript server. Nucleic Acids Res. 2014;42:W320-4. 
26. Kelly LA, Mezulis S, Yates CM, Wass MN, Sternberg MJ. The Phyre2 web portal for protein modeling, prediction and analysis. Nat Protoc. 2015;10(6):845-58.

27. Bradford MM. A rapid and sensitive method for the quantitation of microgram quantities of protein utilizing the principle of protein-dye binding. Anal Biochem. 1976;72:248-54.

28. Laemmli UK. Cleavage of structural proteins during the assembly of the head of bacteriophage T4. Nature. 1970;227:680-5.

29. Trudel J, Asselin A. Detection of chitinase activity after polyacrylamide gel electrophoresis. Anal Biochem. 1989;178(2):362-6.

30. Miller GL. Use of dinitrosalicylic acid reagent for determination of reducing sugar. Anal Chem. 1959;31(3):426-8.

31. Pelletier A, Sygusch J. Purification and characterization of three chitosanase activities from Bacillus megaterium P1. Appl Environ Microbiol. 1990;56(4):844-8.

32. Lee YS, Park DJ, Choi YL. Characterization of maltotriose production by hydrolyzing of soluble starch with a-amylase from Microbulbifer thermotolerans DAU221. Appl Microbiol Biotechnol. 2015;99:3901-11.

33. Lee YS. Isolation and Characterization of a novel cold-adapted esterase, MtEst45, from Microbulbifer thermotolerans DAU221. Front Microbiol. 2016;7:218.

34. Lee YS, Choi YL. Complete genome sequence of cold-adapted enzyme producing Microbulbifer thermotolerans DAU221. J Biotechnol. 2016;229:31-2.

35. Bassler BL, Gibbons PJ, Yu C, Roseman S. Chitin utilization by marine bacteria. J Biol Chem. 1991;266(36):24268-75.

36. Keyhani NO, Roseman S. Physiological aspects of chitin catabolism in marine bacteria. Biochim Biophys Acta. 1999;1473(1):108-22.

37. Souza CP, Almeida BC, Colwell RR, Rivera ING. The importance of chitin in the marine environment. Mar Biotechnol. 2011;13(5):823-30.

38. Shibasaki H, Uchimura K, Miura T, Kobayashi T, Usami R, Horikoshi K. Highly thermostable and surfactant-activated chitinase from a subseafloor bacterium, Laceyella putida. Appl Microbiol Biotechnol. 2014;98(18):7845-53.

39. Fukamizo T. Chitinolytic enzymes catalysis, substrate binding, and their application. Curr Protein Pept Sci. 2000;1(1):105-24.

40. Gohel V, Singh A, Vimal M, Ashwini P, Chhatpar HS. Review-bioprospecting and antifungal potential of chitinolytic microorganisms. Afr J Biotechnol. 2006;5(2):54-72.

41. Halder SK, Jana A, Paul T, Das A, Ghosh K, Pati BR, Mondal KC. Purification and biochemical characterization of chitinase of Aeromonas hydrophila SBK1 biosynthesized using crustacean shell. Biocatal Agric Biotechnol. 2016;5:211-8.

42. García-Fraga B, da Silva AF, López-Seijas J, Sieiro C. Functional expression and characterization of a chitinase from the marine archaeon Halobacterium salinarum CECT 395 in Escherichia coli. Appl Microbiol Biotechnol. 2014;98(5):2133-43.

43. Jamek SB, Nyffenegger C, Muschiol J, Holck J, Meyer AS, Mikkelsen JD. Characterization of two novel bacterial type A exo-chitobiose hydrolases having C-terminal 5/12-type carbohydrate-binding modules. Appl Microbiol Biotechnol. 2017;101(11):4533-46.

44. Larsbrink J, Zhu Y, Kharade SS, Kwiatkowski KJ, Eijsink VGH, Koropatkin NM, McBride MJ, Pope PB. A polysaccharide utilization locus from Flavobacterium johnsoniae enables conversion of recalcitrant chitin. Biotechnol Biofuels. 2016:9:260.

45. Tsuji H, Nishimura S, Inui T, Kado Y, Ishikawa K, Nakamura T, Uegaki K. Kinetic and crystallographic analyses of the catalytic domain of chitinase from Pyrococcus furiosus - the role of conserved residues in the active site. FEBS J. 2010;277(12):2683-95

46. Zhang A, He Y, Wei G, Zhou J, Dong W, Chen K, Ouyang P. Molecular characterization of a novel chitinase $\mathrm{CmChi} 1$ from Chitinolyticbacter meiyuanensis SYBC-H1 and its use in N-acetyl-D-glucosamine production. Biotechnol Biofuels. 2018;11:179.

47. Purushotham P, Sarma PVSRN, Podile AR. Multiple chitinases of an endophytic Serratia proteamaculans 568 generate chitin oligomers. Bioresour Technol. 2012;112:261-9.

48. Bhattacharya D, Nagpure A, Gupta RK. Bacterial chitinase: properties and potential. Crit Rev Biotechnol. 2007;27(1):21-8

49. Yang S, Fu X, Yan Q, Guo Y, Liu Z, Jiang Z. Cloning, expression, purification and application of a novel chitinase from a thermophilic marine bacterium Paenibacillus barengoltzii. Food Chem. 2016;192:1041-8.
50. Adrangi S, Faramarzi MA, Shahverdi AR, Sepehrizadeh Z. Purification and characterization of two extracellular endochitinases from Massilia timonae. Carbohydr Res. 2010;345(3):402-7.

51. Kudan S, Pichyangkura R. Purification and characterization of thermostable chitinase from Bacillus licheniformis SK-1. Appl Biochem Biotechnol. 2009;157(1):23-35.

52. Brzezinska MS, Jankiewicz U, Walczak M. Biodegradation of chitinous substances and chitinase production by the soil actinomycete Streptomyces rimosus. Int Biodeterior Biodegrad. 2013;84:104-10.

53. Meena S, Gothwal RK, Mohan MK, Ghosh P. Production and purification of a hyperthermostable chitinase from Brevibacillus formosus BISR-1 isolated from the Great Indian Desert soils. Extremophiles. 2014;18(2):451-62.

54. Pradeep GC, Choi YH, Choi YS, Suh SE, Seong JH, Cho SS, Bae MS, Yoo JC. An extremely alkaline novel chitinase from Streptomyces sp. CS495. Process Biochem. 2014;49(2):223-9.

55. Rabeeth M, Anitha A, Srikanth G. Purification of an antifungal endochitinase from a potential biocontrol agent Streptomyces griseus. Pak J Biol Sci. 2011;14(16):788-97.

56. Zhang Y, Zhou Z, Liu Y, Cao Y, He S, Huo F, Ringø E. High-yield production of a chitinase from Aeromonas veronii B565 as a potential feed supplement for warm-water aquaculture. Appl Microbiol Biotechnol. 2014;98(4):1651-62.

57. Singh AK, Chhatpar HS. Purification and characterization of chitinase from Paenibacillus sp. D1. Appl Biochem Biotechnol. 2011;164(1):77-88.

58. Yong T, Hong J, Zhangfu L, Li Z, Xiuqiong D, Ke T, Shaorong G, Shigui L. Purification and characterization of an extracellular chitinase produced by bacterium C4. Ann Microbiol. 2005:55(3):213-8.

59. Nawani NN, Kapadnis BP, Das AD, Rao AS, Mahajan SK. Purification and characterization of a thermophilic and acidophilic chitinase from Microbispora sp. V2. J Appl Microbiol. 2002;93(6):965-75.

60. Andreini C, Bertini I, Cavallaro G, Holliday GL, Thornton JM. Metal ions in biological catalysis: from enzyme databases to general principle. J Biol Inorg Chem. 2008;13(8):1205-18.

61. Patil NS, Waghmare SR, Jadhav JP. Purification and characterization of an extracellular antifungal chitinase from Penicillium ochrochloron MTCC 517 and its application in protoplast formation. Process Biochem. 2013;48(1):176-83.

62. García-Fraga B, da Silva AF, López-Seijas J, Sieiro C. A novel family 19 chitinase from the marine-derived Pseudoalteromonas tunicata CCUG 44952T: heterologous expression, characterization and antifungal activity. Biochem Eng J. 2015;93:84-93.

63. Gao C, Zhang A, Chen K, Hao Z, Tong J, Ouyang P. Characterization of extracellular chitinase from Chitinibacter sp. GC72 and its application in GlcNAc production from crayfish shell enzymatic degradation. Biochem Eng J. 2015;97:59-64

64. Annamalai N, Giji S, Arumugam M, Balasubramanian T. Purification and characterization of chitinase from Micrococcus sp. AG84 isolated from marine environment. Afr J Microbiol Res. 2010;4(24):2822-7.

65. Dai DH, Hu WL, Huang GR, Li W. Purification and characterization of a novel extracellular chitinase from thermophilic Bacillus sp. Hu1. Afr J Biotechnol. 2011:10(13):2476-85.

66. Toharisman A, Suhartono MT, Spindler-Barth M, Hwang JK, Pyun YR. Purification and characterization of a thermostable chitinase from Bacillus licheniformis Mb-2. World J Microbiol Biotechnol. 2005;21(5):733-8.

67. Songsiriritthigul C, Lapboonrueng S, Pechsrichuang P, Pesatcha P, Yamabhail M. Expression and characterization of Bacillus licheniformis chitinase (ChiA), suitable for bioconversion of chitin waste. Bioresour Technol. 2010;101(11):4096-103.

68. Kim HS, Timmis KN, Golyshin NP. Characterization of a chitinolytic enzyme from Serratia sp. KCK isolated from kimchi juice. Appl Microbiol Biotechnol. 2007;75(6):1275-83

69. Vaikuntapu PR, Rambabu S, Madhuprakash J, Podile AR. A new chitinaseD from a plant growth promoting Serratia marcescens GPS5 for enzymatic conversion of chitin. Bioresour Technol. 2016:220:200-7.

70. Madhuprakash J, El Gueddari NE, Moerschbacher BM, Podile AR. Catalytic efficiency of chitinase-D on insoluble chitinous substrates was improved by fusing auxiliary domains. PLoS ONE. 2015;10(1):e0116823.

71. Wang X, Chi N, Bai F, Du Y, Zhao Y, Yin H. Characterization of a coldadapted and salt-tolerant exo-chitinase (ChiC) from Pseudoalteromonas sp. DL-6. Extremophiles. 2016;20(2):167-76. 
72. Nagpure A, Gupta RK. Purification and characterization of an extracellular chitinase from antagonistic Streptomyces violaceusniger. J Basic Microbiol. 2013;53(5):429-39.

73. Zakariassen H, Hansen MC, Joranli M, Eijsink VG, Sorlie M. Mutational effects on transglycosylating activity of family 18 chitinases and construction of a hypertrans glycosylating mutant. Biochemistry. 2011;50(25):5693-703.
74. Purushotham P, Podile AR. Synthesis of long-chain chitooligosaccharides by a hypertransglycosylating processive endochitinase of Serratia proteamaculans 568. J Bacteriol. 2012;194(16):4260-71.

75. Sirimontree P, Suginta W, Sritho N, Kanda Y, Shinya S, Ohnuma T, Fukamizo T. Mutation strategies for obtaining chitooligosaccharides with longer chains by transglycosylation reaction of family $\mathrm{GH} 18$ chitinase. Biosci Biotechnol Biochem. 2014;78(12):2014-21.
Ready to submit your research? Choose BMC and benefit from:

- fast, convenient online submission

- thorough peer review by experienced researchers in your field

- rapid publication on acceptance

- support for research data, including large and complex data types

- gold Open Access which fosters wider collaboration and increased citations

- maximum visibility for your research: over $100 \mathrm{M}$ website views per year

At BMC, research is always in progress.

Learn more biomedcentral.com/submissions 